\title{
University of Utah
}

\section{Katharine Coles}

\section{The stranger I become (for Jen Webb)}

\begin{abstract}
:
I am known to walk a lot by modern standards, on most days for seven or more miles. Fitness isn't the point, at least not all of it. Walking spins ideas free; its rhythm puts me in touch with myself, and the distance I travel reminds me I am always loose on the planet. Setting a pace, sallying forth, reminds me, mind comprising as it does every part of the body, not least the heart, which tells me I am frightened or in love before I know to ask. The sensory organs - skin, eyes, ears-fire information constantly. Synthesised and brought to language in the brain, that information creates an ongoing sense of change that we call 'mind', which feels apart from the body but is of the body. Without the body, the brain is a dull grey blob, inert. Like it or lump it.
\end{abstract}

\section{Biographical note:}

Katharine Coles' fifth poetry collection, The Earth Is Not Flat (Red Hen 2013), was written under the auspices of the US National Science Foundation's Antarctic Artists and Writers Program. Her chapbook, Bewilder, was published in 2015 by the International Poetry Studies Institute at the University of Canberra, and her sixth collection, Flight, is due out from Red Hen in 2016. She is also the co-investigator on the Poemage project, which develops software for analysing and visualising sonic relationships in poetry. A professor at the University of Utah, she served from 2006 to 2012 as Utah Poet Laureate and in 2009 and 2010 as the inaugural director of the Poetry Foundation's Harriet Monroe Poetry Institute. She has received grants and awards from the National Endowment for the Arts, the National Endowment for the Humanities, and the Guggenheim Foundation.

\section{Keywords:}

Creative Writing - Walking - Animals - Writing 
Walking is good for thinking, but not vice-versa.

Sharon Bryan (1983)

1.

I am known to walk a lot, by modern standards, on most days for seven or more miles. Fitness isn't the point, at least not all of it. About goats, Sharon Bryan (1983) tells us, 'They keep their balance/by staying in motion' - and balance isn't all physical, at least for me. Walking spins ideas free; its rhythm puts me in touch with myself, and the distance I travel reminds me I am always loose on the planet. Setting a pace, sallying forth, re-minds me, mind comprising as it does every part of the body, not least the heart, which tells me I am frightened or in love before I know to ask. The sensory organs - skin, eyes, ears - fire information constantly. Synthesised and brought to language in the brain, that information creates an ongoing sense of change that we call 'mind', which feels apart from the body but is of the body. Without the body, the brain is a dull grey blob, inert. Like it or lump it.

Walking enacts this change and its constancy. Philosophers have Heidelberg's Philosophenweg, or Philosopher's Walk, which is open also to physicists and mathematicians - many of whom are also great walkers - and even to poets. You can reach it from the station on foot if you're willing to walk forty minutes or so through the less-picturesque suburbs to get there. From it you can contemplate the ruined castle on the other side of the valley, and consider how destruction comes to all bodies, often so slowly we don't notice.

\section{2.}

Before I thought much about dissolution, when I was still a young poet, I worked toward unity, trying to develop a poetic voice, which I believed would distinguish me. I didn't realise that I was also working to fit in, to give the community of poets a handle to grab, a way to say yes, this is $a$ poet, a kind of creature whose vocalisations we recognise as lyric. I wanted to appear at once new and familiar, wild and domesticated. I wanted to teach myself how to write a poem-how to want to write a poem, an essay, any piece at all - that was, as the fashion demanded, about only one thing.

Now, on days when I have too much work to do or the world outside is covered, as this morning, in snow, I walk on a treadmill facing a glass wall looking out over treetops into a canyon. I walk, in other words, toward the edge of a cliff, only a few feet in front of me, an edge that never arrives.

Still, the earth spins. The canyon falls toward the house through Gambel oak at the front and away at the back into wildland. On this shortest day I can hear the frantic, predawn singing of coyotes circling their prey. Once on the NPR program RadioLab, I heard a biologist claim - adamantlythat reports of people hearing coyotes singing to each other are false. He does not have a plausible explanation for exactly what else we might be hearing (Dogs? The howls of our hungry hearts?) or why we would universally identify these calls as belonging to coyotes if they don't. Still, our claims remain unverified, as he says, his voice querulous. Perhaps he imagines us plunging into some mass hallucination, all our unscientific minds, made irrational by winter dark, casting us back into a time not so long ago when we still knew we are prey. 


\section{3.}

For example, the other day, at dusk, I opened my front door to a slightly crazy-eyed pizza delivery man. He was new, and he had just walked down our long, steep driveway under deepening winter shadow and native trees inter-planted with apples. We leave the fruit for the deer who live in the gully running down the hillside next to the house. That evening, the apples long since eaten, they huddled in the clearing on the other side of the carport, holding so still you had to know they were there to see them.

He asked, 'Do you have wild dogs in the neighbourhood?'

I laughed and cocked an ear. I have never, in this neighbourhood, seen a feral dog. I see coyotes all the time, I told him, and even more frequently hear their calls. I pointed at the front walk behind him: the first week we lived in our house, I said, I was standing by the window when a lactating female strolled down it as if she owned the place. Like the time I shared a long gaze with a mountain lion not ten feet in front of me, our look measuring out a much greater than physical distance between us, I was riveted in place, my spine alive with its own electricity.

'Coyotes,' he said, and relaxed. He didn't want to think ordinary dogs, the kind he knows and takes into his home, could sound like that. And the truth is, that biologist notwithstanding, they don't, ever, slide eerie voices up and down a scale tuned to another key, singing out their freedom and their hunger. You don't have to be a scientist to know this. Even calling back to coyotes, as I've heard my dogs do, frantic with fear and excitement, they sound like themselves.

This morning, when I went up to get the paper, I saw in the light snow next to my car a large paw print, canid, enacting absence-in-presence, I was here.

\section{4.}

As the sun rises, finches flutter up from the oaks' shelter by the score to peck at feeders my husband Chris keeps full, changing out types of seed and blocks of suet and insects to attract birds coming through in waves as the seasons change. The small birds draw hawks, which ride the canyon updrafts into the sky or plummet over the roof, sometimes just a few feet away from where I startle at their swift appearances. Occasionally a weasel or fox wanders through, or a lone bobcat stalking the raccoons our feeders also draw, and once, years ago, a moose, gigantic in snow-lit dark, who paused to strip the bark from the aspens out front.

I admit, I don't notice every such event, even when I am facing it squarely. Chris installed a mount for my laptop on the treadmill, and over time I have learned to type at four miles per hour and read at seven, if the reading is easy. I can compose syllabi while walking, or grade papers, or mark up dissertations, or answer the constant stream of anxious emails from students. As you might guess, I don't get carsick either, thank goodness, or airsick, or seasick. But when I do raise my eyes from the screen and cast my gaze beyond the glass, I move not only out of my room, familiar and disorganised for my sole convenience, but out of myself. The canyon, along with its bird population, changes season-by-season. The snow covering everything now in its great blankness will give way to melt and detail, then to buds and leaves that will eventually flame and fall, to grasses that will emerge in soft green then go gold and dry to tinder as fire season arrives. Changes occur not only seasonally: hour-by-hour, even moment-by-moment, the light that defines this landscape shifts and 
slants, brightens and shadows, drags its bright tail across the mountains. Every time I follow my eyes outward, then, I am transported - not only out of my own head, which can forget that its very machinations make it alien to itself, but also into a place made constantly new by the turn of the planet.

\section{5.}

Of course, I prefer to walk outside, where it is harder to sink into myself. I walk often into the foothills out back and sometimes into stranger wildlands, but most intentionally through cities and their adjacent or internalised 'natural', by which I mean humanly remodelled, landscapes. When every summer I visit London for a conference in Kensington, I book a hotel at least three miles away. For years, I stayed at the creaky old Academy in Gower Street, making my way in the morning foot traffic along one of those London streets that keeps changing its name-Goodge to Mortimer to Wigmore - and finally down into Hyde Park and Kensington Gardens. I found the shortest footpath through the woods; when I had time, I stopped on the bridge over the Serpentine and watched the swans admire their reflections in the water. Returning in the evening, I might brave Piccadilly and the teeming theatre district with its brilliant marquees. More recently, I've discovered a strenuously modern hotel in South Bank. From there, the walk takes me along the river and across Westminster Bridge, under Big Ben, and up St James Park on the Birdcage Walk. The trick is not to arrive at the palace gates during the changing of the guards, when the crush of tourists makes passage into Green Park all but impossible and is sure to make me late. Either way, I love emerging from under trees and bird song into an urban mix of shops, restaurants, statues of figures whose names I may or may not know, even crowds.

As Calvino reminds us, an imaginary city haunts every real one, and vice versa (1978 and 1983). When I anticipate traveling to a city I have visited before, or when I am walking through it again, at least three versions of it inhabit the same space. I carry my memory, my imagination, my desire - all interpenetrated and interrupted by the sounds, smells, and sights before me: a new restaurant, a scarlet-painted door I don't remember noticing before though I have walked this Mayfair street a dozen times, each detail in its moment either committed to or lost to memory, often not for the first time. Of course, the passers-by, the faces and the clothes and the conversations, change every time; on a crowded pavement, even if I pass the same person twice, unless we have some reason to speak I probably won't remember.

Don't mistake me. I don't lament the provisionality of cities, of the world or universe, even of memory. I travel out as I travel into myself, seeking to be unmoored. Just now, sitting in my own chair in my own small western city, I am anticipating Philadelphia, Washington DC (in two versions), London again, Frankfurt, Montreal, Winchester, Paris - all on my calendar, all remembered, made up, folded in their own emergent realities. Even the details I remember will not, when I encounter them again, be as I thought.

On my treadmill, looking out, I would never know that, just as the canyon falls away before me, behind me, unrolling in the other direction from the top of the foothill at the top of my drive, lies a city covered, today, in snow-downtown less than two miles away, the university three. I live exactly on the urban-wild interface, on the edge of a neighbourhood that plummets on one side into wilderness, on the other into an urban heart. 
This is my own city - dusty, western, with wide streets and low buildings. I know it so well I forget to see it; even on my treadmill, on the streets of Jakarta or London, on a glacier in Antarctica, forgetting it, I keep it in mind. It lives in me and beyond me. Like every other city, it remains a mystery.

\section{6.}

Perhaps the more recognisable one's voice is as participating in the poetics of the moment, the less recognisably it belongs uniquely to oneself. This is the tension the artist faces. I think how Emily Dickinson's nominal adherence to common measure allows us to think of her as occupying a certain category - call it 'maiden poet'-when she is, on examination, entirely strange, hors catégorie, set loose from time. Frankly, though I at first embraced the emergence of a recognisably contemporary voice with relief if not delight, that voice quickly bored me - or maybe my thoughts bored me, or myself bored me, or all of the above. Maybe I was just undergoing an early mid-life crisis. The pleasures of the familiar, of anything I had mastered and could repeat, diminished. Even the pleasures of technique bored me, at least when technique functioned as an anchor to keep the mind in place rather than as a slingshot to fling me toward some spot I hadn't seen yet, just over the horizon. The urge to move beyond, to understand myself as a stranger, estranged, became more pressing. It got me up from my desk and moved me; I stopped waiting for my poems to arise from within as if unbidden, already spoken.

I went out looking, outside and in. I walked Jakarta and Palembang alone, navigating crumbling sidewalks and eight-lane streets streaming with constant traffic. In Paris, I found a hotel near Paris Nord, and walked to the centre through working-class neighbourhoods I would never have seen, past shop windows showing not designer clothes but hand mixers and old shoes mended. Walked Havana's Old Town and Malecon. I asked the National Science Foundation to send me to Antarctica, where I walked a glacier daily, knowing it could open a crevasse beneath me at any moment. I stopped saying someday.

I was not trying to find myself. I stopped believing I would ever know myself, or that I could even know what either term, 'to know', and 'myself', might mean. Can one - a mind, by which I also mean a body - ever be as whole, intact, bounded as the phrase implies?

The farther I travelled, the stranger I became. Eventually, I took joy in this.

What I wanted, what I want now, is not to avoid danger but to be a little afraid at all times

\section{7.}

as I am when a storm barrels out of the north down the canyon, which concentrates the wind like a long funnel, letting it build speed and sharpen its howl. Icing over, the huge windows visibly bend and flex. I picture the moment of fracture, shards flying inward and after them stinging snow. I think of Dickinson's odd couplet, 'When Winds hold Forests in their Paws/The Universe-is still—', but not because I know what it means. Because I don't.

It isn't hard to be afraid, if I pay attention. 


\section{8.}

Over time, I no longer knew my own work. It shed its carefulness, its overt constructedness, which I had so carefully fostered but no longer seemed to care for. I could no longer look at a page and say whether what I had put there was coherent or not, whether it was a poem or not. Fragments of experience and voice slipped around on the page, hewing close not to my idea of a poem but to the way my mind actually worked. Was that the way my mind actually worked? There on the page was the evidence. I wasn't sure I wanted anyone else to know. I marshalled the fragments as best I could then squirrelled them away. Eventually, I began to take them out and hold them to the light. I had stockpiled scores of them, little odd-bodied things. What then to make of them?

A writer who had admired my previous work asked to read them and found them remote and unrevealing. He wanted me to build the whole story, who what and where, with details, the way I used to.

My canniest friend, the one who knows me best as both writer and person said, 'They are your most intimate work'.

The pressure of expectation, reputation itself, can hold a writer in place. We desire, don't we, to be known; the world desires to know us - or so we believe. I wondered, Why should it? Yet I walk into every Medieval cathedral I pass, looking for art that is literally iconic, that presents images and tells stories that push my buttons every time. One flattened Madonna after another. The blood of saints, plenty of gold leaf, a lump in my throat. Imagine how startling was the Renaissance, how it deepened its depictions of reality into dizzying dimensions and so bewildered before it blissed.

Eventually, I thought I would let others decide, and started to send the poems out - mostly not to editors who knew me, who might be looking for some trace, but to strangers. Later, I gave a reading from the new poems in Canberra, to celebrate the publication of a small chapbook by IPSI, not coincidentally called Bewilder. I hadn't looked at the poems for a while, since they had been assembled. I stopped mid-reading, and blurted, to audience laughter, 'These poems are very strange'.

As my audience necessarily shifted, my circle of first readers narrowed from those who were looking for a specific thing they recognised, that followed certain poetic rules, to those who delighted in watching technique engaged as a catapult, to fling us all into surprise.

\section{9.}

So, like a poem, this essay comes to me in pieces, as a city presents itself in neighbourhoods, as the world flies at us in shards, which our trickster brains fuse together as fast as they arrive so we don't notice it is broken. Arranging. Making sense of, by which I mean subjecting to sensation in the moment, not subjecting to reason, conforming to the known world. A scrap of birdsong. A fragment of language. A firmament, singular enough to have a name, though it is made up and enlightened by billions of stars - themselves comprising atoms and subatomic particles in flight. I too, remember, and you as well, that we are mostly space. If I were small enough, I could sail right through you. For all that, I am not small enough, at least not today. Instead, with you I ride an orb through space, and I don't even have the sense most of the time to let the ride exhilarate me.

An interruption of humming in the blood. Which brings to mind a homing 
as if humming and homing, connected in the ear by sound, forge some more mystical relationship in meaning.

\section{0.}

Meanwhile, Emily Dickinson, my perfect stranger, whom I will neither be nor know.

Meanwhile, my students, their inefficient and radiant mental calisthenics, which I am still trying to convince them are physical feats, performed by meat.

Meanwhile, the mountain lion, whose gaze held me rapt and not so much afraid as exhilarated, never so strange.

Meanwhile, we often leave the sliding door open to the deck. One summer, for no reason we could fathom, the birds that had always stayed on their side of the threshold began flying into the house. I would come home to a bird fluttering among the potted plants and along the window, trying to find home, to find out - the same.

The first one, a disoriented chickadee, I tried to urge back out the open door with a broom. Again and again, I failed - whenever I got the bird near the opening, his freedom, he veered away from it in panic. Finally, he perched, exhausted, in a rubber tree in the corner. Having reached the end of my invention, more frightened for myself than for the bird, I slowly cupped him in my hands. He sat perfectly still except for a thrumming that took his whole body. He was the size of my fist, of my heart, also thrumming. I carried him to the open door, stepped out, and opened my hands. He sat in my palm for two seconds, three, still resting. Then he opened its wings and was gone.

I have done this now a dozen times or more. To take a bird that way and hold it, entire, still frightens me, still thrills, still reminds me I am a stranger even in my own house.

\section{1.}

More and more, I believe in the body, maybe because I have reached an age when the bodies around me are failing. My father, eighty-seven, loses his mind in the most material way, pieces of it, blood flow cut off, literally dying. They call it 'white matter', the accumulated useless sections. The islands that still work are increasingly isolated from each other, so when he has a thought, an idea, a word, he can't connect it to anything else. Not so many years ago, he was a brilliant mathematician, for whom numbers, embodied, hummed, for whom everything was connected. He was an inveterate walker; he paced off mountain ranges, multiplying steps.

At eighty-four, my mother, who has been shrinking for years, continues to erode, losing pieces of herself to the surgeon's knife, to memory, to the past. And then there is my husband, my own age, whose knees have been cut out and replaced with machines. One beloved friend has a hysterectomy; the canny one is haunted by inexplicable and excruciating numbness. Who knew a loss of sensation could come with so much pain, so much senseless making sense.

This is just the beginning. Don't get me started

down time's rabbit hole. 


\section{2.}

I have been asked to write about creativity. Instead, unsure as always what I believe in beyond the senses, I have gone gathering. What have I ever created? Nothing from whole cloth, nothing that didn't pre-exist itself in some other form. Things fall apart. Jacques Barzun (1989) tells us that Shakespeare would have goggled at us if we'd accused him of creativity. He knew it was all loot and pilfer, rearrangement, sleight of hand, the vagaries of memory and imagination, the self encountering itself in stranger form. He knew, as did everyone before the sublime Romantic egomaniacs, that only God creates.

Or, if like me you are a nonbeliever, Nature. And even it - after its first big invention, when anything is possible, time becomes one continuous narrowing, every moment a further limiting of options. Chances are good that I too will end up on a locked ward, my mind in shards. Unless we believe that choice is played out infinitely over infinite universes and our own infinite lives, in which case somewhere I am still writing long, meticulous poems about Kepler, and somewhere (perhaps even here) I sail into old age entirely intact, while somewhere else I have already died in a crevasse in Antarctica or been kidnapped in Sumatra, we are left with small beer.

Why should we be satisfied with small beer, while we still have our minds and even one universe to play in?

I spent my youth trying to become myself-by which I mean, known. I am still failing, happily. I have looked into the eyes of animals - so alert, so coolly curious - and been seen but not known. I have held birds in my hands, felt their entire bodies vibrating, and not known them. I still can't tell if my body is an instrument of language or the other way around. I know only that when language enters me it becomes, with the rest of me, sinew and blood. It sings along my neurons.

Now I find no choice but to relax into the strangeness of voices, and to enter through them a kind of bliss.

\section{Works cited}

Barzun, J 1989 'The paradoxes of creativity’, The American scholar 58.3: 337-351

Bryan, S 1983 'Use Capricious in a sentence', Salt air, Middletown, Connecticut: Wesleyan University Press

Calvino, I 1978 Invisible cities, New York: Harcourt, Brace, Jovanovich

Calvino, I 1983 Marcovaldo: Or seasons in the city, New York: Mariner Books

Coles, K 2015 Bewilder, Canberra: IPSI Press

Dickinson, E 'He fumbles at your Soul' J315, Fr477, Emily Dickinson Archive, www.edickinson.org (accessed 8 January 2017) 